\title{
Integrated Comics and Visible Korean Movies for Laypeople's Learning of Systemic Anatomy
}

\author{
Cómics Integrados y Películas Coreanas Visibles para el Aprendizaje \\ de la Anatomía Sistémica por Personas no Expertas
}

\author{
Beom Sun Chung ${ }^{1}$ Jisoo Kim² \& Min Suk Chung ${ }^{1}$
}

CHUNG, B. S. ; KIM, J. \& CHUNG, M. S. Integrated comics and visible Korean movies for laypeople's learning of systemic anatomy. Int. J. Morphol., 35(3):883-887, 2017.

SUMMARY: The aim of this research was to help the general population learn basic anatomy by providing easy and intriguing comics and Visible Korean movies. Eight significant systems (skeletal, muscular, digestive, respiratory, urinary, genital, cardiovascular, and nervous systems) were explained by the anatomy learning comics. The learning comics were accompanied by humorous comic strips that introduce various episodes about anatomy. The individual systems were also elucidated by videos of surface models and sectioned images that were made from the cadavers. These videos also include annotations and commentaries aiding anatomy comprehension like the documentary films. For users to conveniently access the wanted contents, software with a simple menu was developed. This free software is operable directly on the homepage (anatomy.co.kr); otherwise, the software is downloadable from the same site to be run offline. The combined use of multimedia contents will hopefully promote the general population's interest in and knowledge of anatomy.

\section{KEY WORDS: Anatomy education; Cartoons; Movies; Visible Human Projects; Software.}

\section{INTRODUCTION}

Anatomy, the base of medicine, helps people maintain their health; for example, anatomical knowledge promotes the patients' understanding when listening to their clinicians' explanations. Anatomy also helps children fulfill their curiosity about their own body. The problem is that the current contents available for learning fundamental anatomy are difficult and boring. One reason is that these contents have been made by people who are ignorant of anatomy.

As an experienced anatomist, the corresponding author had already drawn the learning comics "Anna \& Tommy" that deal with systemic anatomy. The learning comics were logical and simple enough to be understood even by elementary students (Kim et al., 2017). Independently, the author created the four-framed comic strips "Dr. Anatophil" that depict mnemonics and humors of anatomy (Park et al., 2011; Shin et al., 2013b).

The corresponding author is also in charge of the Visible Korean project that aims to manufacture the serial sectioned images of a male's whole body (Park et al., 2005) and a female's pelvis (Hwang et al., 2010). The sectioned images can be browsed on the software and will help enhance comprehension of the sectional anatomy (Shin et al., 2011). Furthermore, the sectioned images have been employed to reconstruct the three-dimensional surface models of individual structures (Shin et al., 2015). The surface models can be selected in any combinations and rotated at arbitrary angles with PDF files (Shin et al., 2012, 2013a). The unidirectional movies that show and explain the sectioned images and surface models could be a good educational resource for anatomy beginners.

The objective of this study was to help the general population learn basic anatomy by providing comics and Visible Korean movies in English that are easy and interesting. It was decided to make the free, integrated software where users can conveniently choose to read and watch comics and movies on the skeletal, muscular, digestive, respiratory, urinary, genital, cardiovascular, and nervous systems.

\footnotetext{
${ }^{1}$ Department of Anatomy, Ajou University School of Medicine, 164 Worldcup-ro, Suwon 16499, Republic of Korea.

${ }^{2}$ Ajou University School of Medicine, 164 Worldcup-ro, Suwon 16499, Republic of Korea.

This research was financially supported by the Ministry of Trade, Industry and Energy (MOTIE) and Korea Institute for Advancement of Technology (KIAT) through the International Cooperative R\&D program (Grant number: N0002249).

Raw data of the Visible Korean Human were acquired by the assistance from the Korea Institute of Science and Technology Information.
} 


\section{MATERIAL AND METHOD}

The learning comics were used in this study as they are (Fig. 1). The frames of the learning comics on the eight systems were 512 in number (Table I).

Among more than six hundreds of the comic strips, suitable episodes for each system were picked out (Fig. 1). The chosen episodes of comic strips were totally 113 in number (Table I).

For the production of the movies using surface models and sectioned images, the script was written based on the learning comics. In succession, the anatomical structures to be annotated were determined (Table I).

According to the scenario, the surface models were selected, rotated, and zoomed in or out to be captured for the generation of the movies. The movies were edited on Adobe Premiere Pro CS6 (Adobe Systems, Inc., San Jose, CA). On the still images in the movies, the important structures were labeled by using PowerPoint 2010 (Microsoft Corp., Redmond, WA, USA). The narration was recorded by the second author, an English second language speaker. Likewise, the movies of the sectioned images were elaborated (Fig. 2).

A donated male cadaver's surface models and sectioned images were used for the movies (Park et al., 2005); for the female genital system, another donated female cadaver's data were employed (Hwang et al.).

In the first movie that explains the skeletal system, the steps taken to generate the sectioned images and surface models were also shown in addition.

By using hyper text markup language (HTML), the software titled "Memory Booster of Basic Anatomy" was composed for users to select the wanted contents using a simple table menu (Fig. 3). It was made possible for the software to be directly accessed from the homepage (anatomy.co.kr). Otherwise, the software was made downloadable from the same site to be run offline. The software is free of charge or registration.

\section{RESULTS}

In this section, usage of the comics and Visible Korean movies in the software was explained in comparison with the actual anatomy lecture.

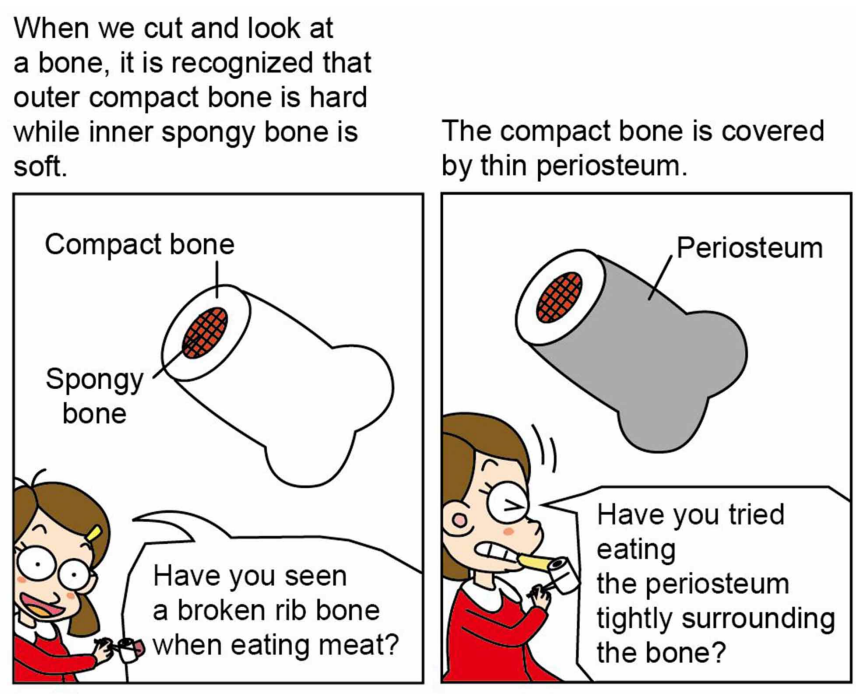

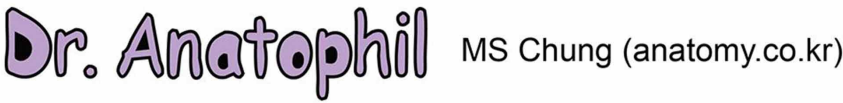

Episode 6: Level of the second rib and button
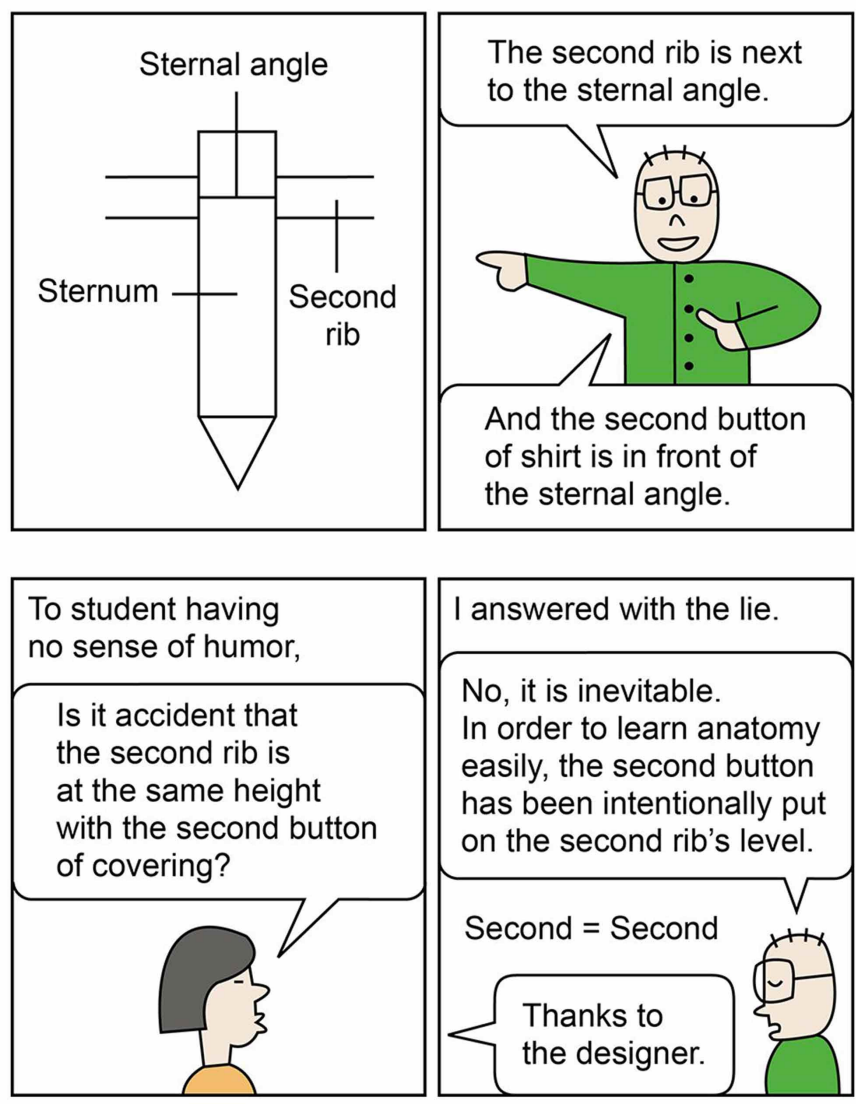

Fig. 1. Learning comics (top) and comic strips (bottom) on the skeletal system. 
Table I. Amounts of multimedia contents according to the systems.

\begin{tabular}{lllcc}
\hline Systems & Leaming comics & Comic strips & Movies of surface models & Movies of sectioned images \\
\hline Skeletal & 47 frames & 20 episodes & 7 minutes $(27)$ & 8 minutes $(22)$ \\
Muscular & 41 frames & 18 episodes & 5 minutes $(15)$ & 8 minutes $(18)$ \\
Digestive & 81 frames & 13 episodes & 6 minutes $(19)$ & 9 minutes $(26)$ \\
Respiratory & 56 frames & 9 episodes & 4 minutes $(15)$ & 6 minutes $(16)$ \\
Urinary & 40 frames & 7 episodes & 4 minutes $(8)$ & 5 minutes $(9)$ \\
Genital & 73 frames & 14 episodes & 9 minutes $(25)$ & 9 minutes $(34)$ \\
Cardiovascular & 80 frames & 14 episodes & 8 minutes $(47)$ & 6 minutes $(15)$ \\
Nervous & 94 frames & 18 episodes & 6 minutes $(13)$ & 57 minutes \\
Total & 512 frames & 113 episodes & 49 minutes &
\end{tabular}

Numbers of the explained anatomical structures.
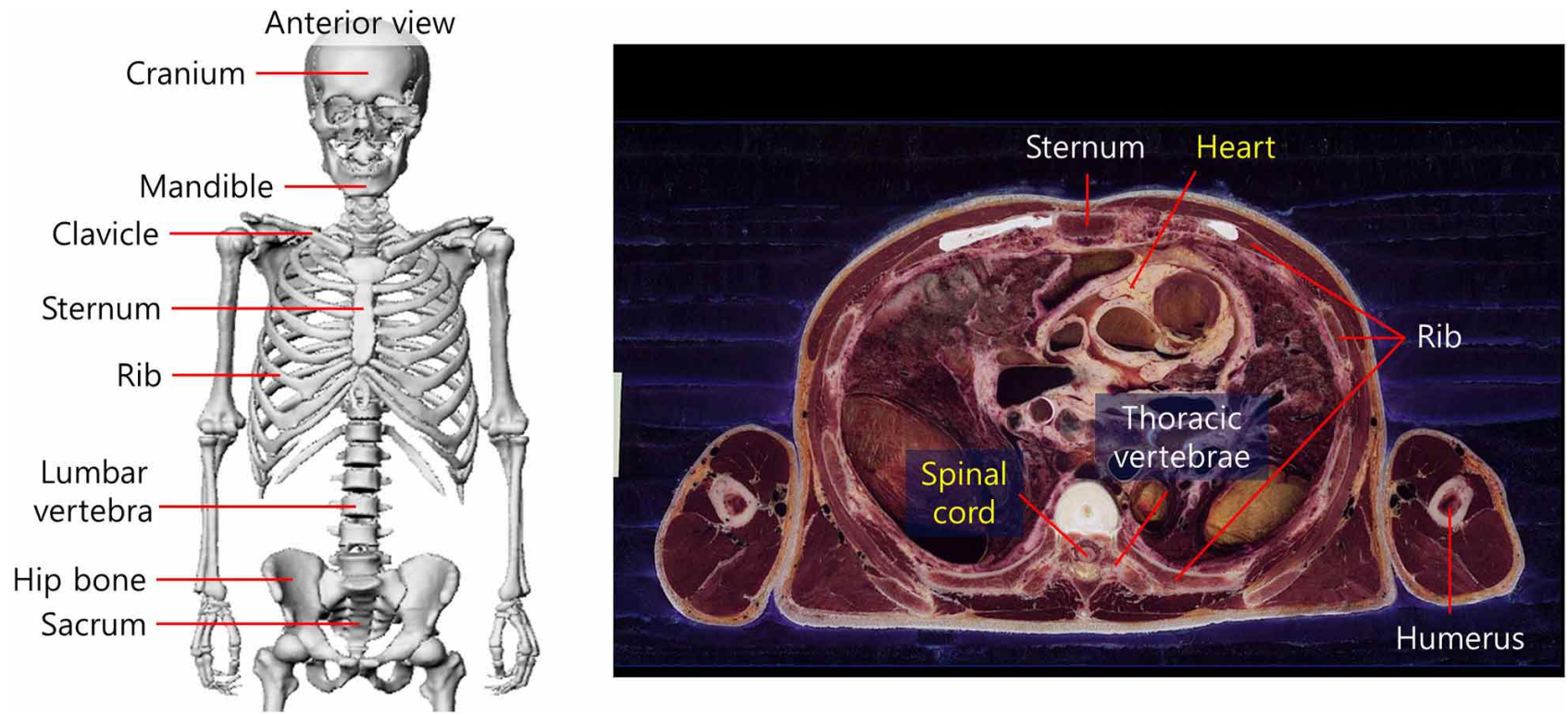

Fig. 2. Movies of the surface models (left) and sectional images (right) that explain the skeletal system. The structures that do not belong to the skeletal system are labeled in yellow.

Among the four kinds of multimedia contents, the core was the learning comics that were most similar to the anatomy lectures. In fact, the learning comics were based on the corresponding author's actual lectures on systemic anatomy for nursing students (Fig. 1) (Kim et al.).

The comic strips were like the jokes during anatomy lectures, which help draw students' attention. The interesting comic strips played the inducement strategy to use this software. A drawback was that many episodes of the comic strips were beyond the learning comics' boundary (Fig. 1) (Park et al., 2011).

The movies of the surface models and sectioned images were like actual dissection since they demonstrated realistic features of the human body while the comics only contained schematic drawings. Unlike other surface modes, which were manually drawn, our surface models were reconstructed from the cadaver's sectioned images (Shin et al., 2015). The sectioned images revealed the realistic color of a living human body (Park et al., 2011). The explained structures in the movies did not deal with information beyond that of the learning comics, so that users watching the movies could easily recall the learning comics that were similar to the anatomy lectures (Fig. 2).

\section{DISCUSSION}

The combined use of multimedia contents in the software is expected to enhance the general population's interest in anatomy. The contents can be used in general education; for an instance, comics and movies on the genital system can be the material used for learning sexual morality. So it is worthy of consideration for the software, equipped with 


\begin{tabular}{|c|c|c|c|c|c|}
\hline$\leftarrow \Leftrightarrow$ & tttp://Nkh. ajou.ac.kr/n & 1.001 & Ory Booste & Basic .... $x$ & 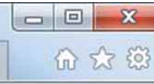 \\
\hline Back to the & nain homepage & & & & \\
\hline & & ry Booster & Basic An & & \\
\hline & & $\begin{array}{l}\text { Learning } \\
\text { comics }\end{array}$ & $\begin{array}{l}\text { Comic } \\
\text { strips }\end{array}$ & $\begin{array}{l}\text { Surface } \\
\text { models }\end{array}$ & $\begin{array}{c}\text { Sectioned } \\
\text { images }\end{array}$ \\
\hline 嘈 & $\begin{array}{l}\text { Skeletal } \\
\text { system }\end{array}$ & $\underline{\varphi}$ & $\underline{\varphi}$ & $\underline{\varphi}$ & $\underline{\varphi}$ \\
\hline a & $\begin{array}{l}\text { Muscular } \\
\text { system }\end{array}$ & $\underline{p}$ & $\underline{\varphi}$ & $\underline{\varphi}$ & $\underline{p}$ \\
\hline 近 & $\begin{array}{l}\text { Digestive } \\
\text { system }\end{array}$ & $\underline{\varphi}$ & $\underline{v}$ & $\underline{v}$ & $\underline{\varphi}$ \\
\hline ? & $\begin{array}{c}\text { Respiratory } \\
\text { system }\end{array}$ & $\underline{p}$ & $\underline{\varphi}$ & $\underline{\varphi}$ & $\underline{\varphi}$ \\
\hline C & $\begin{array}{l}\text { Urinary } \\
\text { system }\end{array}$ & $\underline{p}$ & $\underline{v}$ & $\underline{v}$ & $\underline{v}$ \\
\hline 5 & $\begin{array}{l}\text { Genital } \\
\text { system }\end{array}$ & $\underline{\varphi}$ & $\underline{\varphi}$ & $\underline{\varphi}$ & $\underline{\varphi}$ \\
\hline$\pi$ & $\begin{array}{l}\text { Cardiovascular } \\
\text { system }\end{array}$ & $\underline{p}$ & $\underline{\varphi}$ & $\underline{p}$ & $\underline{p}$ \\
\hline 8 & $\begin{array}{l}\text { Nervous } \\
\text { system }\end{array}$ & $\underline{v}$ & $\underline{v}$ & $\underline{\underline{p}}$ & $\underline{\varphi}$ \\
\hline
\end{tabular}

Fig. 3. Initial page of the software with the menu table consisting of the eight systems (eight rows) and the four available kinds of multimedia content (four columns). The heart symbol " $\vee$ " in the menu table can be clicked to watch the corresponding contents.

adequate explanations, to be installed in science museums. It is also expected for the health care professional trainees and medical students to utilize the software for their main or preliminary study.

Users of the software can benefit with additional anatomical experience in the identical homepage (anatomy.co.kr). They can see the learning comics of the remaining systems (e.g., articular system, embryology) (Kim et al.) and the other hundreds of comic strips that were excluded from the software (Park et al., 2011).

Users of the software are also able to operate the PDF files of surface models as well as the browsing software packages of sectioned images (Shin et al., 2011, 2012, 2013a). The interactive operations of the PDF files and browsing software are more sophisticated and informative than the one-way viewing of the presented software.

In addition, the homepage provides a textbook on regional anatomy "Memory Booster of Regional Anatomy" and a reading matter on anatomy "Dr. Anatophil's Essay." From these supplementary contents, users can obtain more knowledge and pleasure.

Comics, surface models, and sectioned images on the software can be captured. Anyone is allowed to employ the captured images for other purposes (e.g., lecture slide) excluding for commercial purposes.

The software can be possibly updated by adding different multimedia data. Examples are furthermore pictures and movies of dissected cadavers and movies of anatomy lectures. After much more added data, a searching tool for anatomy terms will be needed.

The opinons of the software users are going to be collected and analyzed through a questionnaire. Their opinions will be helpful in upgrading and utilizing the software.

Our method to make software by HTML can be comfortably repeated by other anatomists. This method is suggested because anatomists can spend their precious time not for computer programming but for developing good quality contents.

The authors have produced integrated anatomy software of the comics and Visible Korean movies, which is expected to be helpful in anatomy learning by the general public and medical students.

\section{ACKNOWLEDGEMENTS}

This research was financially supported by the Ministry of Trade, Industry and Energy (MOTIE) and Korea Institute for Advancement of Technology (KIAT) through the International Cooperative R\&D program (Grant number: N0002249).

Raw data of the Visible Korean Human were acquired by the assistance from the Korea Institute of Science and Technology Information.

CHUNG, B. S. ; KIM, J. \& CHUNG, M. S. Cómics integrados y películas coreanas visibles para el aprendizaje de la anatomía sistémica por personas no expertas. Int. J. Morphol., 35(3):883-887, 2017.

RESUMEN: El objetivo de esta investigación fue ayudar a la población en general en el aprendizaje de la anatomía básica, a través de cómics, fáciles de entender e intrigantes, y de películas coreanas. Ocho sistemas anatómicos (esquelético, muscular, digestivo, respiratorio, urinario, genital, cardiovascular y nervioso) fueron explicados por medio del aprendizaje de la anatomía con 
cómics. Los cómics fueron acompañados por cómics graciosos que introducen varios episodios sobre anatomía. Los sistemas también fueron explicados a través de videos de modelos de superficie e imágenes seccionadas realizadas a partir de los cadáveres. Estos videos también incluyen anotaciones y comentarios que ayudan a la comprensión de la anatomía. Para que los usuarios accedieran convenientemente al contenido deseado, se desarrolló un software con un menú sencillo. Este software libre puede ser manejado directamente en el sitio web anatomy.co.kr; de lo contrario, el software se puede descargar desde el mismo sitio para ser usado fuera de línea. El uso combinado de contenidos multimedia promoverá el interés de la población en general y el conocimiento de la anatomía.

PALABRAS CLAVE: Educación en Anatomía; Dibujos animados; Películas; Proyectos Humanos Visibles; Software.

\section{REFERENCES}

Hwang, S. B.; Chung, M. S.; Hwang, Y. I.; Park, H. S.; Har, D. H.; Shin, D. S.; Shin, B. S. \& Park, J. S. Improved sectioned images of the female pelvis showing detailed urogenital and neighboring structures. Korean J. Phys. Anthropol., 23(4):187-98, 2010.

Kim, J.; Chung, M. S.; Jang, H. G. \& Chung, B. S. The use of educational comics in learning anatomy among multiple student groups. Anat. Sci. Educ., 10(1):79-86, 2017

Park, J. S.; Chung, M. S.; Hwang, S. B.; Lee, Y. S.; Har, D. H. \& Park, H. $S$. Visible Korean human: improved serially sectioned images of the entire body. I. E. E. E. Trans. Med. Imaging, 24(3):352-60, 2005.

Park, J. S.; Kim, D. H. \& Chung, M. S. Anatomy comic strips. Anat. Sci. Educ., 4(5):275-9, 2011.

Shin, D. S.; Chung, M. S.; Park, H. S.; Park, J. S. \& Hwang, S. B. Browsing software of the Visible Korean data used for teaching sectional anatomy. Anat. Sci. Educ., 4(6):327-32, 2011.

Shin, D. S.; Chung, M. S.; Park, J. S.; Park, H .S.; Lee, S.; Moon, Y. L. \& Jang, H. G. Portable document format file showing the surface models of cadaver whole body. J. Korean Med. Sci., 27(8):849-56, 2012.

Shin, D. S.; Jang, H. G.; Hwang, S. B.; Har, D. H.; Moon, Y. L. \& Chung, M. S. Two-dimensional sectioned images and three-dimensional surface models for learning the anatomy of the female pelvis. Anat. Sci. Educ., 6(5):316-23, 2013a

Shin, D. S.; Kim, D. H.; Park, J. S.; Jang, H. G. \& Chung, M. S. Evaluation of anatomy comic strips for further production and applications. Anat. Cell Biol., 46(3):210-6, 2013b.

Shin, D. S.; Lee, S.; Park, H. S.; Lee, S. B. \& Chung, M. S. Segmentation and surface reconstruction of a cadaver heart on Mimics software. Folia Morphol. (Warsz.), 74(3):372-7, 2015.

\author{
Corresponding author: \\ Min Suk Chung \\ Department of Anatomy \\ Ajou University School of Medicine \\ 164 Worldcup-ro \\ Suwon 16499 \\ KOREA
}

Email: dissect@ajou.ac.kr

Received: 18-04-2017

Accepted: 05-06-2017 